\title{
Subordination vs. agency/resistance in South Africa: Virgins bargaining their way through higher education
}

\author{
Stander, Sunelle \\ Stellenbosch University \\ standersunelle@gmail.com
}

\begin{abstract}
Oppression manifests itself in various ways, such that intersections between different forms of oppression can be identified. This is also true for women living in South Africa, a country that has for years been plagued by many forms of oppression (racism, sexism, classism, etc.). Women are, amidst various forms of oppression, often left with few alternative options but to bargain with various forms of gender relations as a means to obtain basic human rights (like education). Recent student protests have highlighted the discriminating ways in which black students are kept from obtaining higher education. The so called "maidens bursary", awarded to underprivileged girls who vow to stay virgins throughout their studies, will be used as a case study that examines an alternative route to which underprivileged women may resort in order to obtain a quality education. The notion of patriarchal bargaining will then be used to illumine the often unrecognized, complex and interwoven relationship between subordination and agency/resistance that operates within the South African context.
\end{abstract}

Key words

Maiden bursaries; virginity testing; patriarchal bargaining; female agency

\section{Introduction: Maiden bursaries}

News headlines were recently filled with outrage about the decision of the Uthukela District Municipality to introduce a new category of bursaries to matriculating girls (eNCA 2016, Khoza 2016). The maiden bursary is a special category that was awarded to 16 female virgins who vowed to abstain from sex and remain virgins for the duration of their studies. If these women were to lose their virginity during this time, the bursaries would be withdrawn. The female Uthukela District Mayor, Dudu Mazibuko, initiated 
this category of bursary. According to her it serves to reward young women for staying "pure". Regular virginity testing, in an attempt to ensure the students' purity, is a condition for the bursary to be awarded (eNCA 2016).

\section{What does virginity testing entail?}

Virginity testing refers to "the practice and process of inspecting girls to determine if they are sexually chaste" (Leclerc-Madlala 2010: 412). Traditionally, it formed part of the reed dance festival that "existed in pre-colonial Zulu religiosity and was abandoned as more and more Zulus became converted to Christianity" (Phiri 2003: 65). Historically, during lobola negotiations, a woman's virginity would prove that her mother had looked after her well and would thereby ensure an additional cow for her mother, which was called "the eleventh cow" (Leclerc-Madlala 2010: 418, cf. Scorgie 2002: 61). "Thus the virginity of the girl was not for herself but her mother, father and husband" (Phiri 2003: 66, cf. Scorgie 2002: 58, cf. Leclerc-Madlala 2010: 418). The festival was abandoned for a period of time, but was revived by two local women - Andile Gumede and Nomagugu Ngobese (Phiri 2003: 65, Scorgie 2002: 57, cf. Leclerc-Madlala et al. 2009: 20) - "to...promote pre-marital chastity among young girls in the province, and to thereby reinstate female virginity [ubuntombi] with the symbolic importance it once had" (Scorgie 2002: 57). Beverly Haddad (2006: 136) shows that "faith is central to the lives of African Christian women, many of whom endure immense daily suffering". The church and many African cultures have played a significant role in the upholding of the belief in the value of virginity. This also seems to be the case for Nomagugu Ngobese, who is one of the women behind the revival of virginity testing in the Zulu culture. Nomagugu was a member of the Roman Catholic Church. According to Phiri (2003: 65) it is therefore easy to link her acceptance of the reed dance ceremony with the emphasis on virginity found in Catholic Mariology.

1 While this paper examines a particular manifestation of the value of virginity in the Zulu culture, namely, virginity testing for maiden bursary eligibility, it is worth acknowledging that many cultures, Western and non-Western alike, advocate a preference for virginity among unmarried women in other ways that are beyond the scope of this study. 
Older women in the community perform virginity testing in two ways (Haddad 2006: 150). Sometimes girls are required to lie on their backs with their legs open, to allow for each girl's exposed genitals to be examined (Phiri 2003: 66, Scorgie 2002: 58, cf. Haddad 2006: 150). The individuals' names and test results are then carefully recorded. Confirmed virgins are, according to customs, celebrated by women in the community and receive a certificate and a smearing of white clay on their foreheads as sign of their purity. Those who do not pass the test are taken aside for questioning to determine whether the girl lost her virginity through consensual sex or rape and are then encouraged to abstain from sex in the future (Scorgie 2002: 58).

Though an attempt is often made to avoid explicitly drawing attention to the girls who fail the test, the point of the testing is "to render visible what has, until then, remained invisible..." (Scorgie 2002: 58). Those who fail the test can therefore hardly escape unnoticed. The cumulative effect of each step of virginity testing "collectively adds to the creation of virgins as a distinct social and conceptual category" (Scorgie 2002: 58).

Scorgie explains how girls who are found to be virgins form groups with distinct identities that are affirmed through the creation of special group names and uniforms. It is custom for these girls to meet on a regular basis. Other girls are encouraged to participate in virginity testing if they wish to share in the group identity (Scorgie 2002: 59). A fair amount of the virginity testing movement's energy goes into deflecting girls' attention "away from forming sexual liaisons with boys" (Scorgie 2002: 64). News reports explained that the maiden bursaries are similarly "intended to encourage young girls to stay pure and focus on their education” (Khoza 2016).

\section{Controversy surrounding virginity testing}

Substantial controversy surrounds the practice of virginity testing in general and the maiden bursary awards in particular. A variety of approaches to virginity testing can be found amongst African women theologians. While some regard it as part of the essence of a particular culture, others regard it as acts of injustice toward women (Phiri 2003: 73). Isabel Phiri makes it clear that most of the criticism for virginity testing comes from a Western worldview, which itself can become oppressive to women when outsiders pass value judgements on a specific cultural practice (Phiri 2003: 
75, 76). Phiri (2003: 76) therefore argues for the consideration of personal experience when evaluating a cultural practice. It must be noted that while some of the negative views and judgements of virginity testing will now be discussed, the aim is not to make a value judgement of virginity testing itself, but rather to show how women exercise agency and negotiate gender relations when faced with various forms of oppression and struggle.

Human Rights and Gender Commissions, as well as women fighting for gender equality through other social formations, view virginity testing as "a new form of violation and violence against women"2 (Leclerc-Madlala 2010: 412). According to these groups, the practice of virginity testing goes against specifications in the national constitution "that uphold rights to privacy, bodily integrity, and outlaw all forms of gender discrimination" (Leclerc-Madlala 2010: 412). Leclerc-Madlala (2010: 413) states that virginity testing is socially oppressive and therefore asks for an in depth exploration when considering the contributing factors. This approach suggests a consideration beyond "tradition" alone, in order to take into account the "complexity of the decision-making processes within a culture and the competing demands on individuals" (Leclerc-Madlala 2010: 413).

One of the issues that seem to have an influence on women's decisionmaking processes when it comes to virginity testing is the role that AIDS plays in their lives. AIDS is a gender issue because the majority of individuals infected with AIDS in sub-Saharan Africa are female (Phiri 2003: 63, Leclerc-Madlala 2010: 411). Virginity testing is, according to those advocating the practice and the maiden bursaries, a preventative measure taken to combat the spread of the disease. However, the merit of such claims is questioned from various perspectives. Given the increase in anal sex among young girls, concerns have been raised that the practice might have the opposite effect.

One of the aspects of virginity testing that has come under scrutiny is that its underlying assumptions seem to be connected to the value of virginity.

2 Virginity testing is even at times compared to female circumcision. Although the practice of virginity testing is not regarded as physically harmful, individuals opposing virginity testing refer to harmful similarities that can be identified in both practices. "While the two practices are very different in nature, both are viewed as socially oppressive" (Leclerc-Madlala 2010: 413) 
Virginity is in many contexts and societies linked with perceptions of purity, such that women are divided into two distinct categories: "good girls" on the one hand and "bad girls" on the other. Girls in these societies who choose not to remain virgins are often marginalized and stigmatized as impure. "Anthropologists argue that virginity is usually highly valued in societies that seek to control women" (Bruce 2004: 9). According to Scorgie (2002: 64), the association of female virginity with the concepts of pride and dignity also has a strong influence in the discourses of virginity testing. While the mark of purity is physically inscribed on the bodies of those who pass the test, shame and stigmatization often seem to become symbolic writings onto the bodies of those who fail.

Women who become pregnant before marriage are often stigmatized so that "sexual abstinence is...constructed as an end in itself, quite separate from its role in enabling fertility control and the prevention of STD and HIV transmission" (Scorgie 2002: 64). This is, according to Scorgie, evident in the negative responses from advocates of virginity testing to other forms of contraception, which are often condemned as alternatives to virginity testing in the fight against AIDS. One aim of virginity testing is therefore "...to encourage women to preserve themselves", that is, to stay pure (Scorgie 2002: 64). Naidu (2008: 88) shows that "beyond being historically constructed to represent honour at the family level, women's bodies are, in many cultural contexts, also inscribed to symbolise the integrity and honour of entire nations". Such honour seems to be at stake when supporters of virginity testing embrace the idea that the pride and dignity of communities may be restored through these rituals (Scorgie 2002: 65).

Those opposed to virginity testing also draw attention to the understanding of sexual responsibility that underlies this ritual. Naidu (2008: 86) notes that "traditionally...virginity scripts constrain women more than men and the responsibility of maintaining the virginity of both men and women appears to fall squarely on women". According to Scorgie (2002: 66) this imbalance in responsibility can also be detected in the logic of the practice of virginity testing. Research on virginity testing done by Naidu (2008: 87) among female Zulu students indicates that women often perceive the emphasis put on female virginity as overbearing and unfair, because men do not receive the equivalent amount of pressure and judgement from society. Scorgie notes that a perception is created that boys can only be reached 
and kept from having sex through girls' abstinence and thus male sexual responsibility is ignored. In many contexts, men measure their masculinity according to sexual activity, such that boys put pressure on girls to engage in pre-marital sex as a means to prove their own "manliness". Scorgie (2002: 67) therefore refers to a sexual double standard that operates within the discourse of virginity testing.

In this context...discourses of blame and accusation... are being fixed along the "fault lines" of local understandings of sexuality, gender and morality. Where responsibility for sexual abstinence is placed so unambiguously on the shoulders of young girls, the implication that they are therefore also responsible for the spread of the disease is only a short step away (Scorgie 2002: 67).

In the last analysis, then it is "the responsibility of women to control the epidemic” (Hoosen \& Collins 2004: 500). Leclerc-Madlala (2010: 413) similarly illustrates that virginity testing "is another thread reinforcing a web of meaning that places women and women's sexuality at the epicentre of blame for the current AIDS epidemic amongst the Zulu". She therefore regards virginity testing as a gendered response to the gendered problem of HIV/AIDS.

Discussion on the meaning of "pride" and "dignity" (Scorgie 2002: 65) surfaces when opponents of virginity testing argue that "the way in which the ceremony requires girls to expose their genitals in public" (Scorgie 2002: 65) violates their rights for respect and personal dignity as described in the South African Constitution - "a violation made all the more serious in cases where girls did not willingly choose to be tested" (Scorgie 2002: 65). Some of the female students that formed part of Naidu's research on virginity testing felt violated and humiliated by this practice. Hoosen and Collins (2004: 500) therefore believe that virginity testing entrenches "gender inequity since it undermines women's struggle to take control over their bodies".

According to Hoosen and Collins (2004: 500) virginity testing endorses the subordinate position that women have in society and keeps women "silenced, controlled and at risk". Leclerc-Madlala (2010: 420) therefore states: 
At both a conceptual and practical level, virginity testing is enacting (and I would suggest further entrenching) the gender inequality that is propelling the spread of HIV/AIDS. Lining up girls for genital inspection is a contemporary social drama that reflects long existing and deeply entrenched historical anxieties about the control of female sexuality that are linked to issues of fertility and social reproduction.

There is a widespread belief, then, that virginity testing reinforces gender inequalities and thereby robs women of their pride and dignity.

\section{Reasons behind the popularity of virginity testing and the maiden bursaries}

Despite the backlash against virginity testing and the patriarchal, oppressive overtones identified by various feminists, law experts, the media and female Zulu students themselves, virginity testing has gained popularity in South Africa. In addition to the many men who are supportive of virginity testing, its popularity among both younger and older women is especially striking. "Older rural women who bear the brunt of caring for the illegitimate children of their daughters and granddaughters" are especially supportive of the movement (Bruce 2004: 11). Despite Naidu's research exposing some of the negative experiences of female Zulu students themselves, several were still found to support virginity testing as a preventive measure for HIV/AIDS (Naidu 2008: 87). Similarly, the female Uthukela mayor, Dudu Mazibuko, defends the initiative of maiden bursaries by stating that the young women in question and the community are supportive (Ngcobo 2016).

\subsection{Subordination vs. Agency}

It is easy to assume that the women advocating the maiden bursaries and virginity testing are mere victims of patriarchal cultural practices and have no agency. When approaching the relationships between subordination and agency, Mary McClintock Fulkerson (1994) makes the observation that feminists tend to restrict the subject "woman" in feminist theology to women who identify with feminism or other liberation theologies and see themselves as needing emancipation from patriarchal practices, structures 
and systems. Women who support oppressive practices are, often in an over-simplified way, understood through what Louise Kretzschmar identifies as "internalised oppression" - oppression that takes place "when the oppressed accept or internalise the negative perceptions that those in power have of them" and regard these oppressive "perceptions, customs and systems" as legitimate and appropriate (Kretzschmar 1998: 173). The expectation is then that these women will react positively to a process of awakening their conscience and will seek liberating alternatives once they realize that practices regarded as patriarchal are oppressing them.

Fulkerson, however, sees the internalized oppression approach as oversimplified and restricted. She urges feminist theologians to broaden the feminist subject to also include the experiences and lives of women who do not identify with feminism or other liberation theologies. Her approach asks for an in-depth exploration of the complexities of women's experiences and contexts. The intricate formation of "multiple identities (emphasis mine)" should therefore become essential to theological thinking about women's agency/resistance and subordination (Fulkerson 1994: 7). Keeping Fulkerson's approach in mind, it is therefore important to gain a better understanding of the wider South African context, in which the women whose lives are affected by virginity testing live.

\subsection{The South African context}

In the light of the HIV/AIDS pandemic in South Africa, Bruce (2004: 7) notes the importance of considering the "various aspects of sexuality" and "the various social, cultural and economic factors that impact on the way individuals exercise their sexuality". Connell and Messerschmidt (2005: 842-843) show that the gender position that people adopt is constrained by their contexts and circumstances: "One is not free to adopt any gender position in interaction simply as a discursive or reflexive move. The possibilities are constrained massively by embodiment, by institutional histories, by economic forces, and by personal and family relationships". Issues like race, class, etc. therefore have an influence on the gender position that persons adopt. When attempting to understand the complexities of the lives of women living in South Africa, it is important to acknowledge that women fall victim to various forms of oppression: racism, sexism and classism. Intersections between these forms of oppression can be identified 
in the specific lives of black and underprivileged women living in South Africa and, therefore, in the lives of the women granted the maiden bursaries.

The HIV/AIDS pandemic in South Africa forces many women "to deal with socio-economic and cultural oppression" (Haddad 2006: 136). Statistics South Africa (2014: 27) shows that "there are significant differences in poverty levels between the population groups in South Africa", where the latest statistics show that more than $90 \%$ of poor people are black Africans (Statistics South Africa 2014: 27, cf. Durrheim, Mtose \& Brown 2011: 17). The oppression and inequality that black people are still experiencing in South Africa has been highlighted by recent student protests that have swept across the country since October 2015. These protests show that the unequal position of black individuals, relative to white individuals living in South Africa, is also visible in the sphere of education. According to the Human Sciences Research Council, the graduation rate for white students surpassed that of black students (Letseka \& Maile 2008: 1). Female students also remain marginalised and are under-represented at university level (Potgieter 2008), where white and male postgraduates continue to predominate (Badat 2010: 20, cf. Snyder 2010: 15). High tertiary education fees have effectively excluded the poor (Letsekat \& Maile 2008: 2, 3), contributing to the ongoing under-representation of black students.

It is therefore clear that black students in South Africa still do not enjoy equal opportunities relative to white students at tertiary level, with female black students being affected the worst, because they are both black and female. These students are still expected to achieve the same results as white students, despite lacking equal circumstances and opportunities. The maiden bursary awards were granted to black, underprivileged female students. This information is therefore especially important when attempting to understand the popularity and support that virginity testing in general and the maiden bursaries in particular have received.

\subsection{Patriarchal bargaining}

Patriarchal bargaining will now be proposed as an approach to virginity testing and the maiden bursaries that might help us gain a better understanding of the complexities and struggles of black women in South Africa, as well as the gender position and choices that women make 
with regards to their sexuality. Patriarchal bargaining will therefore be suggested as an approach that might help us gain a better understanding of the possible reasons behind the popularity of virginity testing and the maiden bursaries among female advocates. The aim is to identify ways in which these women can exercise agency in the midst of their contexts.

Patriarchal bargaining is an approach that complicates the dichotomy that is often assumed to exist between subordination and resistance/agency, and emphasises the complicated and rich nature of women's lives and experiences (Mahmood 2005: 6). According to this approach, women are not merely the receptors of patriarchal rules and customs, but also often use their gender positions and sexuality - even those that might be perceived as oppressive - to gain certain positions and benefits in society, such as security, financial benefits, social status, and, as will be proposed in what follows, education.

While patriarchal bargaining can be identified in both men's ${ }^{3}$ and women's lives, Denise Kandiyoti applies this approach to the lives of women when she refers to the fact that "women strategize within a set of concrete constraints" (Kandiyoti 1998: 284). Patriarchal bargaining is thus used to indicate that a set of rules and scripts exists that regulates gender relations. Both males and females submit to and accommodate these rules and scripts, while at the same time often contesting, redefining and renegotiating them (Kandiyoti 1998: 284). Class and ethnicity also have an influence on the strategies that women choose to gain benefits and security within a patriarchal and unequal society and culture. According to Kandiyoti, a "systematic analysis of women's strategies and coping mechanisms can help to capture the nature of patriarchal systems in their cultural, classspecific, and temporal concreteness and recall how men and women resist, accommodate, adapt, and conflict with each other over resources, rights, and responsibilities" (1998: 285). Patriarchal bargains do not only influence women's rational choices and decisions, but also the "more unconscious aspects of their gendered subjectivity, since they permeate the context of their early socialization, as well as their adult cultural milieu" (Kandiyoti

3 For a further reading on the ways in which patriarchal bargaining is evident in the lives of men, see: Wilcox, W. B. 2004. Soft patriarchs, new men: How Christianity shapes fathers and husbands. Chicago: The University of Chicago Press. 
1988: 285). When writing about HIV/AIDS in South Africa, Beverly Haddad (2006: 153) notes that "forms of resistance are present in rural women who are under severe surveillance by culture, church, and society, but they are not necessarily overt or easily understood". These forms of resistance that often go unnoticed are "conducted in more earnest, for higher stakes, and against greater odds" than are often recognized (Scott 1990: 200 in Haddad 2006: 153).

Kandiyoti shows that various manifestations of patriarchy, or in this case different forms of gender relations, "present women with distinct "rules of the game" and call for different strategies to maximize security and optimize life options with varying potential for active or passive resistance in the face oppression" (1988:284). Oduyoye, for example, makes it clear in her work, Introducing African women's theology, that "women face daily survival issues of managing their hearth-holds and they give up their time and energy, muster their ingenuity and creativity to assure life for others" (2001:107). The view, however, exists that women do not make sacrifices "as they are in fact acting in self-interest, they are protecting their own survival, saving their own faces and avoiding the taunt, blame and ridicule of the society" (Oduyoye 2001:107).

Considering the rise of HIV/AIDS in South Africa that has had devastating effects on the lives of black women, drastic measures taken by older women to subvert these effects can be expected. Women who advocate virginity testing therefore seem to be strategizing within an area of struggle, namely, the spread of HIV/AIDS, by redeploying the practice of virginity testing in order to gain control of a situation that seems to be out of control. "For Nomagugu and the rest of the mothers and grandmothers who support the ritual, it is about economic and social survival" (Phiri 2003: 74). After all, these women not only bear the financial burden of caring for orphaned grandchildren, but also have to deal with the loss pertaining to the untimely deaths of their children.

"For African...women, culture is a societal dimension that has complex and contradictory implications with respect to their interests, freedom and rights" (Kuumba 2006: 113). It is, according to Kuumba (2006: 113), true that "established/'traditional' African...cultures are replete with practices and perceptions that hegemonise patriarchal interests and 
women's oppression" (Kuumba 2006: 113). It must also be noted, however, that African women have throughout history used-bargained-and, in some cases, transformed cultural practices "as a progressive force in their efforts to facilitate liberation from various forces of oppression" (Kuumba 2006: 120). Women's agency should therefore be recognized when they subvert "the hegemonic meanings of cultural practices and redeploy them for their own interests and agendas" (Mahmood 2005:6). These forms of resistance have both structural and symbolic components that have been used to "oppose structures and processes of racist, patriarchal, classist and heterosexist domination" (Kuumba 2006: 120).

Considering the larger South African context, it appears that female advocates of virginity testing are not mere victims of what many consider to be oppressive patriarchal norms that are forced on them. Such women, in fact, show agency by deploying their gender relations, virginity and practices, that some regard as oppressive, to gain certain benefits: security, social status and basic human rights, like education. These women are therefore using the practice of virginity testing to resist the effects that a racialized and unequal society has established around them and can be seen to bargain with their own virginity in an attempt to gain opportunities that would otherwise not be possible.

In a country where specifically black and female students do not enjoy the same privileges as their white and male counterparts, the female students who receive the maiden bursary awards have few other opportunities to obtain a quality education and ensure a better future. They choose to use their virginity as a means to obtain this basic human need. One of the female advocates of the maiden bursaries and virginity testing stated, in reference to young Zulu girls, "We want them to be checked to make sure that they have something to look forward to when they get to [their final year of high school]" (News 24a 2016). One of the young women who received the maiden bursary award also noted that she "never thought remaining a virgin would open so many doors for her" (News 24b 2016). For students who can otherwise not afford tertiary education, remaining a virgin therefore seems like a small price to pay to ensure a brighter future with more educational opportunities. One of the students even believes staying a virgin will enable her to give back to her community and help her family out of financial trouble (News 24b 2016). 


\section{Conclusion}

Considering the intersections that exist between different forms of oppression experienced by black women in South Africa, it seems as if bargaining with gender relations and virginity may help them to ensure a brighter future. Though testing for and celebrating virginity is by some considered an oppressive reality for women in general, particular women may choose to comply with these practices in exchange for what they receive in return: high social regard relative to other women, praise from their societies, and, in the case of education, bursaries that offer them upward mobility that is otherwise difficult to obtain in a white, patriarchal culture. This article has argued that these women's compliance with virginity testing and positive attitudes towards the maiden bursaries are not only understandable, given the unequal society in which they live, but may, in fact, be regarded as a form of agency.

\section{Bibliography}

Badat, S. 2010. The challenge of transformation in higher education and training institutions in South Africa. Development Bank of Southern Africa. [Online].Available from http://www.dbsa.org/ EN/About-Us/Publications/Documents/The\%20challenges $\% 20$ of $\% 20$ transformation $\% 20$ in\%20higher\%20education $\% 20$ and $\% 20$ training\%20institutions\%20in\%20South\%20Africa\%20by\%20 Saleem\%20Badat.pdf. [Accessed: 10 January 2010].

Bruce, P. 2004. Virginity: Some master myths a study of biblical and other ancient references to virginity in the context of HIV/AIDS in South Africa. Neotestamentica. 38(1) 7-27.

Connell, R.W. \& Messerschmidt, J.W. 2005. Hegemonic masculinity: Rethinking the concept. Gender \& Society, 19(6) 829-859.

Durrheim, K., Mtose, X., Brown, L., 2011, Race troubles: Race, identity and inequality in post-apartheid South Africa, New York: Lexington Books.

eNCA. 2016. HRC to probe Maiden Bursaries. [Online] Available from: https://www.enca.com/south-africa/hrc-probe-maiden-bursaries [Accessed 16 June 2016]. 
Fulkerson. M.M. 1994. Changing the subject: Women's discourses and feminist theology. Minneapolis: Fortress Press.

Haddad, B. 2006. Living it out: Faith resources and sites as critical to participatory learning with rural South African women. Journal of Feminist Studies in Religion. 22(1) 135-154.

Hoosen, S. \& Collins, A. 2004. Sex, sexuality and sickness: Discourses of gender and HIV/AIDS among KwaZulu-Natal women. South African Journal of Psychology. 34(3) 487-505.

Kandiyoti, D. 2009. Bargaining with patriarchy. Gender and Society. 2(3) 274-290.

Khoza, A. 2016a. Girls be warned: Lose your virginity, you lose your bursary. [Online] News24. Available from: http://www.news24.com/ SouthAfrica/News/municipality-warns-maidens-lose-your-virginitylose-your-bursary-20160122 [Accessed 13 April 2016].

Khoza, A. 2016b. Staying a virgin has opened doors for me - bursary winner. [Online] News24. Available from: https://www.enca.com/ south-africa/hrc-probe-maiden-bursaries [Accessed 13 April 2016].

Kretzschmar, L. 1998: Gender, women and ethics. In: Kretzschmar, L. \& Hulley, L. (eds.) Questions about life and morality: Christian ethics in South Africa today. Pretoria: J L van Schaik Publishers. 169-184.

Kuumba, M.B. 2006. African women, resistance cultures and cultural resistances. Agenda: Empowering Women for Gender Equity. 68. 112121.

Letseka, M. \& Maile, S. 2008. High university drop out rates: A threat to South Africa's future. [online] HSRC Policy Brief. March 2008. Human Sciences Research Council. Available from: http://www.hsrc. ac.za/uploads/pageContent/1088/Dropout\%20rates.pdf [Accessed 16 June 2016].

Leclerc-Madlala, S., Simbayi, L. C., Cloete, A. 2009. The sociocultural aspects of HIV/AIDS in South Africa. In: Rohleder, P., Swartz, L., Kalichman, S.C., Simbayi, L.C. (eds.) HIV/AIDS in South Africa 25 years on: Psychosocial Perspectives. New York: Springer. 13-25. 
Leclerc-Madlala, S. 2010. Virginity testing: Managing sexuality in a maturing HIV/AIDS epidemic. In: Grinker, R.R., Lubkemann, S.C., Steiner, C. (eds.) Perspectives on Africa: A reader in culture, history and representation. $2^{\text {nd }}$ edn. Oxford: Blackwell Publishing Ltd. 411422.

Mahmood, S. 2005. Politics of piety: The Islamic revival and the feminist subject. Princeton: Princeton University Press.

Naidu, M. 2008, Anthropology of female body: site of high-jacking within the AIDS discourse, Agenda,

Ngcobo, Z. 2016, KZN Mayor defends virginity testing for maidens bursary programme. [Online]. Available from http://ewn. co.za/2016/01/26/Practice-of-virginity-testing-for-bursary-isacceptable [Accessed 13 April 2016].

Oduyoye, M.A. 2001. Introductions in feminist theology: Introducing African Women's Theology. Sheffield: Sheffield Academic Press Ltd.

Phiri, I.A. 2003. Virginity testing? African women seeking resources to combat HIV/AIDS. Journal of Constructive Theology. 9(1) 63-78.

Potgieter, C. 2008. The intersection of race and gender in higher education. National Higher Education Conferenc: Institutional cultures and higher education leadership: "Where are the women?" Cape Town: HERS-SA, the Department of Education, The Council of Higher Education (CHE), and Higher Education South Africa (HESA).

Scorgie, F. 2002. Virginity testing and the politics of sexual responsibility: Implications for AIDS intervention. African Studies. 61(1) 55-75.

Snyder, C.R. 2014. A woman's place: Women of colour navigating doctoral education in South Africa. International Journal of Multicultural Education. 16(2) 15-35.

Statistics South Africa. 2014. Poverty trends in South Africa: An examination of absolute poverty between 2006 and 2011. 